\section{Stroke prevention}

Background and epidemiology:

This past May and June, the US Centers for Disease Control and Prevention and the Public Health Agency of Canada each dedicated a month, respectively, to raising awareness about stroke. Each year in Canada stroke occurs in 50000 people and accounts for $7 \%$ of all deaths. About $5 \%$ of men over the age of 65 have been affected by stroke; the proportion is only slightly lower for women. Care for stroke patients accounts for $2.1 \%$ of Canadian health care expenditures. ${ }^{1}$ The burden of this devastating disease can be reduced through a combination of clinical interventions targeted at high-risk individuals and broader population-health initiatives to control chronic diseases. ${ }^{2}$

The causes and mechanisms of stroke vary. Half of cases are atherothrombotic in origin, with a further $25 \%$ attributable to small-vessel lacunar disease and $20 \%$ to cardioembolism. ${ }^{1}$ Common conditions that underlie stroke include atherosclerosis, atrial fibrillation, hypertension, dyslipidemia and diabetes. ${ }^{1}$ such as age, gender, ethnicity and genetic factors, cannot be modified. Others, if moderated, can greatly reduce both the likelihood of stroke and the severity of its outcomes: physical inactivity, hypertension, smoking, dyslipidemia, atrial fibrillation, diabetes and heavy use of alcohol. ${ }^{2}$

Clinical management: Prevention of stroke in individuals with underlying disease was recently and thoroughly reviewed in $C M A 7 .{ }^{1}$ Highlights of that review are shown in Table 1.

Timely access to medical care for thrombolysis (if indicated) and early treatment with ASA can improve stroke outcomes. Individuals at risk of stroke need to be educated that the warning signs of stroke include sudden weakness, trouble speaking, sudden loss of vision
Some risk factors for stroke, and severe unusual headache or dizziness. This must especially be reinforced in patients who experience a transient ischemic attack (TIA), since the risk of stroke is elevated in the first 48 hours after a TIA and the risk of having a stroke within a year of a TIA is $10 \%-14 \% .^{3}$

Prevention: A stroke-prevention strategy aimed at the general public that involves education and regulatory changes is potentially less costly than and as effective as those that target high-risk populations. For example, about $26 \%$ of Canadian adult men and $18 \%$ of women have hypertension, defined as a diastolic blood pressure of $90 \mathrm{~mm} \mathrm{Hg}$ or more, or a systolic pressure of $140 \mathrm{~mm} \mathrm{Hg}$ or more. About $40 \%$ of such people are unaware they have hypertension. Data from largecohort studies have suggested that a mere $2 \mathrm{~mm} \mathrm{Hg}$ reduction in a population's mean diastolic blood pressure can decrease the number of new strokes by as much as $14 \%$, which is compar- able to targeted medical treatment of all patients with a diastolic pressure of $95 \mathrm{~mm} \mathrm{Hg}$ or higher. ${ }^{2}$

Since many of the risk factors for stroke also contribute to the burden of other chronic diseases, there is growing interest in embedding stroke-prevention programs within a broader strategy of control of chronic disease. This includes special attention to those risk factors that contribute to the largest proportion of new stroke cases: physical inactivity, hypertension and smoking. ${ }^{2}$

\section{Erica Weir CMAF}

\section{References}

1. O'Rourke F, Dean N, Akhtar N, Shuaib A. Current and future concepts in stroke prevention [review]. CMAJ 2004;170(7):1123-33.

2. Young TK, Hachiniski V. The population approach to stroke prevention: a Canadian perspective. Clin Invest Med 2003;26:78-86.

3. Hill MD, Yiannakoulias N, Jeerakathil, Tu JV, Svenson LW, Schopflocher DP. The high risk of stroke imattack: a population-based study. $\mathrm{Neu}$ rology 2004;62:2015-20. mediately after transient ischemic

\section{Table 1: Agents to manage underlying disease to prevent stroke}

\begin{tabular}{|c|c|}
\hline Intervention & Take-home message \\
\hline Antiplatelet agents & $\begin{array}{l}\text { As a primary preventive measure, antiplatelet agents do not reduce the risk } \\
\text { of ischemic stroke among patients without vascular disease. ASA remains a } \\
\text { first-line therapy in the secondary prevention of atherothrombotic stroke after } \\
\text { a first episode, although combination therapy with ASA and dipyridamole is } \\
\text { also justified in the absence of coronary artery disease. Clopidogrel is } \\
\text { recommended if the patient is ASA-intolerant. }\end{array}$ \\
\hline Anticoagulants & $\begin{array}{l}\text { Heparin should be avoided in the treatment of acute stroke. Treatment with } \\
\text { warfarin is indicated for patients with atrial fibrillation without prior TIA or } \\
\text { stroke. Warfarin is also indicated as primary stroke prevention for patients } \\
\text { with prosthetic heart valves and for recent acute myocardial infarction } \\
\text { (within } 3 \text { months) with apical hypokinesis or thrombus, and as secondary } \\
\text { prevention in the presence of antiphospholipid antibody. }\end{array}$ \\
\hline Antihypertensives & $\begin{array}{l}\text { Thiazides, ACE inhibitors or a combination thereof should be considered } \\
\text { as first-line therapy. The use of additional antihypertensive therapies depends } \\
\text { on the clinical circumstances. }\end{array}$ \\
\hline $\begin{array}{l}\text { Lipid-lowering } \\
\text { agents }\end{array}$ & $\begin{array}{l}\text { All patients with prior TIA, ischemic stroke or risk factors for vascular disease } \\
\text { should be treated with a statin, irrespective of their serum cholesterol level. }\end{array}$ \\
\hline $\begin{array}{l}\text { Carotid } \\
\text { endarterectomy }\end{array}$ & $\begin{array}{l}\text { Carotid endarterectomy remains the definitive treatment in patients with } \\
\text { a symptomatic stenosis of the internal carotid artery of } 70 \% \text { or higher and } \\
\text { in selected patients with a stenosis of } 50 \%-69 \% \text {. It is not currently } \\
\text { recommended for asymptomatic disease. }\end{array}$ \\
\hline
\end{tabular}

Note: $\mathrm{ASA}=$ acetylsalicylic acid, $\mathrm{ACE}=$ angiotensin-converting enzyme, $\mathrm{TIA}=$ transient ischemic attack. Adapted from O'Rourke et al,' CMAJ 2004; 170 (7):1123-33. 